\title{
FINANCIALIZATION AND STAGNANT CAPITAL ACCUMULATION IN CHINA
}

\author{
Guanchun Liu ${ }^{1}$, Chien-Chiang Lee ${ }^{2}$ \\ ${ }^{1}$ School of Public Economics \& Administration, Shanghai University of Finance \& \\ Economics, Shanghai, P.R. China. Email: liuguanchun1@126.com \\ ${ }^{2}$ Department of Finance, National Sun Yat-sen University, Kaohsiung, Taiwan. Email: \\ cclee@cm.nsysu.edu.tw
}

\begin{abstract}
Using a semi-annual data of listed non-financial corporations from 2007 to 2015, this paper investigates the effect of financialization on capital accumulation in China. The results show that increased financial profit crowds out real investment, especially for small and private firms. Furthermore, the effect of financialization reverts to be positive in the long-run and its cumulative effect manifests a "U-type" pattern.
\end{abstract}

Keywords: Financialization; Capital accumulation; Polynomial inverse lag; China. JEL Classifications: D21; E22; G11.

Article history:

Received : March 2, 2018

Revised : : May 25, 2018

Accepted : July 24, 2018

Available online : July 31, 2018

https://doi.org/10.21098/bemp.v21i1.941 


\section{INTRODUCTION}

Financialization is a recent concept refers to a broad range of phenomena, including the globalization of financial markets, the shareholder value revolution and the rise of incomes from financial investment (Stockhammer, 2004). In this paper, financialization is defined as the increasing trend of financial profit obtained by non-financial corporations. The phenomenon reflects the shareholder revolution from 'retain and reinvest' to 'downsize and distribute' (Lazonick and O'Sullivan, 2000), and the return gap between financial and fixed assets (Demir, 2009).

As the largest developing country, China has been growing rapidly at a rate of $10 \%$ before 2010, but economic growth declined since 2010 with a rate of $6.9 \%$ in 2015. As the driving force behind growth, real investment in China during the period 2007-2015 was stagnant and decreased gradually after 2011. During this time, the financial profit of non-financial corporations experienced an upward trend (see Figure 1). One question, therefore, is: can financialization explain the decline in real investment in China? This paper aims to answer this question.

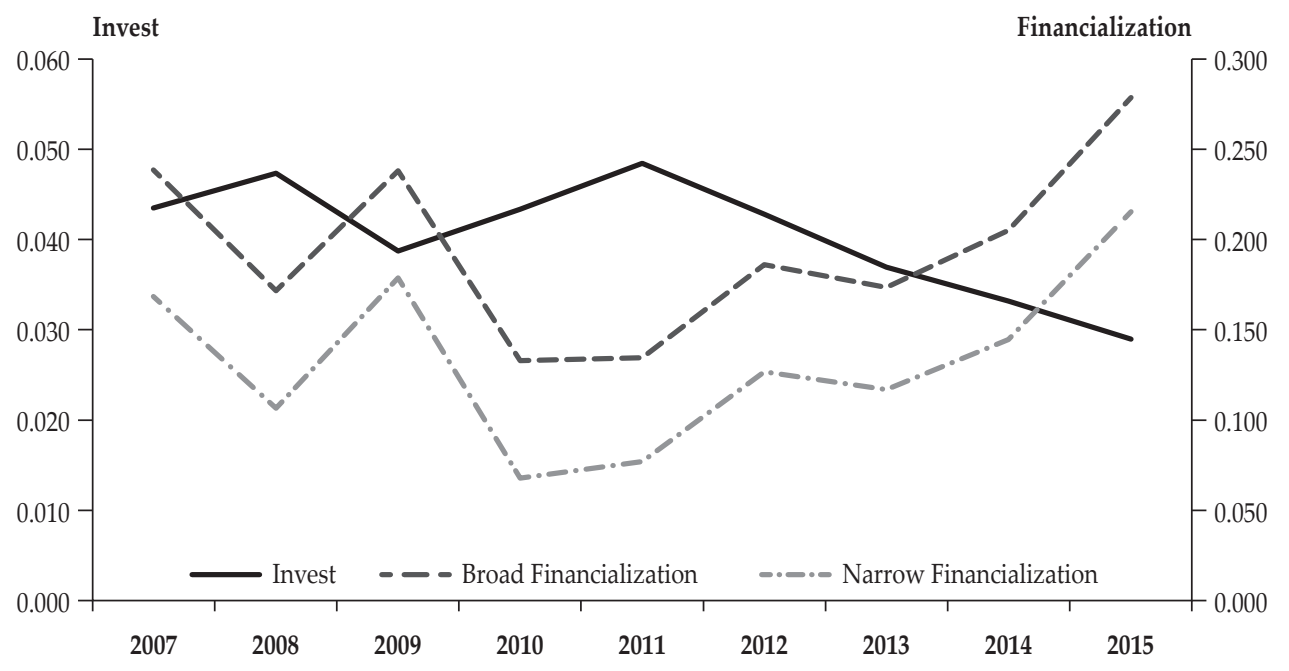

Figure 1. Financialization and Real Investment over 2007-2015

The portfolio choice between financial and real investments is not a new topic in the economics literature. On the one hand, depending on the respective rate of return, firms decide to allocate their portfolios between real and financial investments, and hence there is a substitution effect between real and financial assets (Tobin, 1965; Tornell, 1990). On the other hand, liquidity-based investment theories and financing constraint hypothesis point out that, incomes from financial investment can be used to finance real investment in the future (Smith and Stulz, 1985).

In practice, most research studies support the theory of substitution effect, but they only care about the short-run impact of financialization and ignore its long-run effect on real investment. For example, using macroeconomic or firm- 
level data, Stockhammer (2004), Orhangazi (2008), and Demir (2009) find that financialization has a negative and significant impact on capital accumulation, while Kliman and Williams (2005) point out that financialization is not the reason for productive investment.

In this study, we examine the effects of financialization on China's capital accumulation across time horizons, through performing the traditional regression and the Polynomial Inverse Lag (PIL) procedure borrowed from Mitchell and Speaker (1986). Our findings reveal that the instant impact of financialization on real investment starts negative but reverts to be positive after 9 years, and the cumulative effect presents a "U-type" pattern.

\section{DATA AND METHODOLOGY}

Given the highly liquid nature of financial investments, a better choice would be to use quarterly data (Demir, 2009). In this paper, we utilize the semi-annual data of listed non-financial corporations over 2007-2015. The data is obtained from Wind dataset, and we drop those firms with less than six consecutive years of data.

Following Chaney et al. (2012), we consider the following model:

$$
\begin{aligned}
\operatorname{Inv}_{i t}= & \alpha+\delta \operatorname{Inv}_{i, t-1}+\beta_{1} \text { Fps }_{i, t-1}+\beta_{2} \operatorname{Lev}_{i, t-1}+\beta_{3} \text { Roe }_{i, t-1} \\
& +\beta_{4} \text { Size }_{i t}+\beta_{5} T q_{i t}+\beta_{6} C f o_{i t}+\mu_{i}+\eta_{t}+\varepsilon_{i t},
\end{aligned}
$$

where Inv denotes firm real investment, using the sum of cash paid for the acquisition of fixed and intangible assets as well as other long-term assets to total assets; Fps denotes financialization, measured by the share of financial profit to net profit. Several control variables for eliminating the impacts of firm's heterogeneous characters are considered to add in the model, including debt-to-assets ratio (Lev), the return rate on equity (Roe), the natural logarithm of total assets (Size), Tobin's $\mathrm{Q}(T q)$ and operational cash flow $(C f o)$. In addition, $\mu_{i}$ and $\eta_{t}$ respectively present the firm- and time-specific effects; $\varepsilon_{i t}$ is error term.

Following Arrighi (1994), we use two indicators for firm's financialization, namely Fps1 and Fps2, which represent the broad and narrow definitions. Specifically, broad financial profit is defined as the sum of earnings from fair value changes and income from other financial operations. Considering the fact that investment for joint ventures does not flow into financial assets directly, narrow financial profit equals broad financial profit minus earnings from joint ventures.

To investigate the effects of financialization on the firm investment across time horizons, the PIL framework of Mitchell and Speaker (1986) is considered:

$$
\begin{aligned}
\operatorname{Inv}_{i t}= & \alpha+\delta \operatorname{Inv}_{i, t-1}+\sum_{j=1}^{\infty} \omega_{j} \text { Fps }_{i, t-j}+\beta_{2} \text { Lev }_{i, t-1}+\beta_{3} \text { Roe }_{i, t-1} \\
& +\beta_{4} \text { Size }_{i t}+\beta_{5} T q_{i t}+\beta_{6} \text { Cfo }_{i t}+\mu_{i}+\eta_{t}+\varepsilon_{i t},
\end{aligned}
$$


where

$\omega_{j}=\sum_{\tau=2}^{n} \frac{b_{\tau}}{(j+1)^{\tau}}, \quad j=1,2, \cdots, \infty$.

Set $n=7$ and $m=9$, the simplified version of PIL method can be written as:

$$
\begin{aligned}
\operatorname{In} v_{i t} & =\alpha+\delta \operatorname{In} v_{i, t-1}+\sum_{\tau=2}^{6} b_{\tau} \sum_{j=1}^{8} \frac{F p s_{i, t-j}}{(j+1)^{\tau}}+\beta_{2} \operatorname{Lev}_{i, t-1}+\beta_{3} \operatorname{Roe}_{i, t-1} \\
& +\beta_{4} \operatorname{Size}_{i t}+\beta_{5} T q_{i t}+\beta_{6} C f o_{i t}+\mu_{i}+\eta_{t}+\varepsilon_{i t} .
\end{aligned}
$$

Then, we can obtain the instant effect $\omega_{j}$ and the cumulative effect $\sum \omega_{j}$ of financialization on real investment over different time horizons.

\section{EMPIRICAL RESULTS}

We estimate Eq. (1) by employing a system Generalized Method of Moments (GMM) estimator proposed by Arellano and Bover (1995) and Blundell and Bond (1998). Following Brown and Petersen (2011), we treat all financial variables (including Fps, Lev, Roe, and Cfo) as potentially endogenous and use lagged levels dated $t-3$ and $t-4$ as instruments for the regression in differences, and lagged differences dated $t$-2 for the regression in levels.

Table 1 presents the estimation results based on Eq. (1) and robust standard errors are provided to obtain heteroskedasticity-robust estimates. It shows that for the broad and narrow definitions of financialization, there is a significantly negative relationship between financial profit and real investment with the coefficient -0.0020 (-0.0026). Past financial investment does not support current real investment, reflecting a change in the managerial preferences towards shorttermism and financial investments and hence affect real investment adversely. An interesting finding is that the effect of leverage on real investment is negative, although not significant. One possible reason is the increasing payments to financial markets in the form of dividends and stock buybacks by nonfinancial firms (Orhangazi, 2008). In addition, other explanatory variables have the expected signs. 
Table 1.

The Effects of Financialization on Real Investment

\begin{tabular}{|c|c|c|c|c|c|c|c|c|}
\hline \multirow{3}{*}{$\frac{\operatorname{Inv} v_{i, t-1}}{}$} & \multicolumn{4}{|c|}{ Broad Financialization (Fps1) } & \multicolumn{4}{|c|}{ Narrow Financialization (Fps2) } \\
\hline & \multicolumn{2}{|c|}{ OLS } & \multicolumn{2}{|c|}{ GMM } & \multicolumn{2}{|c|}{ OLS } & \multicolumn{2}{|c|}{ GMM } \\
\hline & $\begin{array}{c}0.3475^{* * *} \\
(0.0095)\end{array}$ & $\begin{array}{c}0.3443^{* * *} \\
(0.0092)\end{array}$ & $\begin{array}{c}0.4767^{* * *} \\
(0.0079)\end{array}$ & $\begin{array}{c}0.4262^{* * *} \\
(0.0088)\end{array}$ & $\begin{array}{c}0.3471^{* * *} \\
(0.0095)\end{array}$ & $\begin{array}{c}0.3441^{* * *} \\
(0.0092)\end{array}$ & $\begin{array}{c}0.4760^{* * *} \\
(0.0079)\end{array}$ & $\begin{array}{c}0.4258^{* * *} \\
(0.0088)\end{array}$ \\
\hline$F p s_{i, t-1}$ & $\begin{array}{c}-0.0009^{* * *} \\
(0.0002)\end{array}$ & $\begin{array}{c}-0.0006^{* * *} \\
(0.0002)\end{array}$ & $\begin{array}{c}-0.0028^{* * *} \\
(0.0003)\end{array}$ & $\begin{array}{c}-0.0020^{* * *} \\
(0.0003)\end{array}$ & $\begin{array}{c}-0.0013^{* * *} \\
(0.0002)\end{array}$ & $\begin{array}{c}-0.0009^{* * *} \\
(0.0002)\end{array}$ & $\begin{array}{c}-0.0036^{* * *} \\
(0.0003)\end{array}$ & $\begin{array}{c}-0.0026^{* * *} \\
(0.0003)\end{array}$ \\
\hline$L e v_{i, t-1}$ & & $\begin{array}{c}-0.0005^{* *} \\
(0.0003)\end{array}$ & & $\begin{array}{c}-0.0063^{* * *} \\
(0.0007)\end{array}$ & & $\begin{array}{c}-0.0005^{* *} \\
(0.0003)\end{array}$ & & $\begin{array}{c}-0.0063^{* * *} \\
(0.0007)\end{array}$ \\
\hline $\operatorname{Roe}_{i, t-1}$ & & $\begin{array}{c}0.0138^{* * *} \\
(0.0025)\end{array}$ & & $\begin{array}{c}-0.0076^{* *} \\
(0.0034)\end{array}$ & & $\begin{array}{c}0.0131^{* * *} \\
(0.0025)\end{array}$ & & $\begin{array}{c}-0.0093^{* * *} \\
(0.0034)\end{array}$ \\
\hline Size $_{i t}$ & & $\begin{array}{c}0.0033^{* * *} \\
(0.0009)\end{array}$ & & $\begin{array}{c}0.0035^{* * *} \\
(0.0006)\end{array}$ & & $\begin{array}{c}0.0033^{* * *} \\
(0.0009)\end{array}$ & & $\begin{array}{c}0.0034^{* * *} \\
(0.0006)\end{array}$ \\
\hline$T q_{i t}$ & & $\begin{array}{c}0.0014^{* * *} \\
(0.0003)\end{array}$ & & $\begin{array}{c}0.0001 \\
(0.0002)\end{array}$ & & $\begin{array}{c}0.0014^{* * *} \\
(0.0003)\end{array}$ & & $\begin{array}{c}0.0001 \\
(0.0002)\end{array}$ \\
\hline$C f o_{i t}$ & & $\begin{array}{c}0.0264^{* * *} \\
(0.0038)\end{array}$ & & $\begin{array}{c}0.0979^{* * *} \\
(0.0055)\end{array}$ & & $\begin{array}{c}0.0263^{* * *} \\
(0.0037)\end{array}$ & & $\begin{array}{c}0.0978^{* * *} \\
(0.0055)\end{array}$ \\
\hline Obs. & 27866 & 27866 & 27866 & 27866 & 27866 & 27866 & 27866 & 27866 \\
\hline R2 & 0.3104 & 0.3155 & & & 0.3108 & 0.3157 & & \\
\hline $\operatorname{AR}(2)$ & & & 0.219 & 0.216 & & & 0.254 & 0.215 \\
\hline Hansen & & & 0.741 & 0.648 & & & 0.632 & 0.699 \\
\hline
\end{tabular}

Notes: All specifications use firm and year fixed effects and cluster observations at firm level; Robust standard errors are in parentheses; Constant terms are not reported; ${ }^{*}{ }^{* *}$ and ${ }^{* * *}$ refer to significance at $10 \%, 5 \%$ and $1 \%$ levels, respectively; All tests are given by their p-values. The Hansen is the tests of over-identifying restrictions. AR(2) serial correlation test is the second-order serial correlation for the first-differenced residuals.

Further, to explore the heterogeneous effects of financialization on real investment for firms with different types, Table 2 takes disaggregation by firm size and ownership a step further and reports the estimation results. Obviously, the roles of financialization are sensitive to firm size and ownership. As for small and private firms, the coefficients of financialization are larger than those of large and state-owned firms. The results are not entirely surprising since firms with small size and private ownership have higher productivities in China, so investing financial assets will crowd out real investment more than those of firms with large size and state-owned ownership. 
Table 2

Heterogeneous Effects of Financialization on Firms' Real Investment

\begin{tabular}{|c|c|c|c|c|c|c|c|c|}
\hline & \multicolumn{4}{|c|}{ Firm Size } & \multicolumn{4}{|c|}{ Ownership } \\
\hline & \multicolumn{2}{|c|}{ Large } & \multicolumn{2}{|c|}{ Small } & \multicolumn{2}{|c|}{ State-owned } & \multirow{2}{*}{$\begin{array}{c}\text { Private } \\
\text { Broad }\end{array}$} & \multirow[b]{2}{*}{ Narrow } \\
\hline & Broad & Narrow & Broad & Narrow & Broad & Narrow & & \\
\hline \multirow[t]{2}{*}{$I n v_{i, t-1}$} & $0.4516^{* * *}$ & $0.4516^{* * *}$ & $0.3904^{* * *}$ & $0.3896^{* * *}$ & $0.4429^{* * *}$ & $0.4427^{* * *}$ & $0.4096^{* * *}$ & $0.4083^{* * *}$ \\
\hline & $(0.0141)$ & $(0.0141)$ & $(0.0109)$ & $(0.0109)$ & (0.0118) & $(0.0118)$ & $(0.0124)$ & $(0.0124)$ \\
\hline \multirow[t]{2}{*}{$F p s_{i, t-1}$} & -0.0005 & $-0.0007^{*}$ & $-0.0027^{* * *}$ & $-0.0035^{* * *}$ & $-0.0011^{* * *}$ & $-0.0015^{* * *}$ & $-0.0028^{* * *}$ & $-0.0037^{* * *}$ \\
\hline & (0.0004) & $(0.0004)$ & $(0.0003)$ & $(0.0004)$ & (0.0003) & $(0.0003)$ & $(0.0005)$ & $(0.0006)$ \\
\hline \multirow{2}{*}{$\operatorname{Lev}_{i, t-1}$} & $-0.0083^{* * *}$ & $-0.0083^{* * *}$ & $-0.0025^{* * *}$ & $-0.0025^{* * *}$ & $-0.0056^{* * *}$ & $-0.0056^{* * *}$ & $-0.0056^{* * *}$ & $-0.0055^{* * *}$ \\
\hline & $(0.0010)$ & $(0.0010)$ & $(0.0006)$ & $(0.0006)$ & $(0.0008)$ & $(0.0008)$ & $(0.0010)$ & $(0.0010)$ \\
\hline \multirow[t]{2}{*}{$\operatorname{Roe}_{i, t-1}$} & $-0.0151^{* *}$ & $-0.0157^{* *}$ & $0.0077^{* * *}$ & $0.0058^{* *}$ & $-0.0130^{* * *}$ & $-0.0142^{* * *}$ & 0.0045 & 0.0022 \\
\hline & $(0.0066)$ & $(0.0066)$ & $(0.0026)$ & $(0.0027)$ & $(0.0042)$ & $(0.0042)$ & $(0.0047)$ & $(0.0048)$ \\
\hline \multirow[t]{2}{*}{ Size $_{i t}$} & $0.0060^{* * *}$ & $0.0060^{* * *}$ & $0.0020^{* * *}$ & $0.0019^{* *}$ & $0.0037^{* * *}$ & $0.0037^{* * *}$ & $0.0022^{* *}$ & $0.0021^{* *}$ \\
\hline & $(0.0011)$ & $(0.0011)$ & $(0.0008)$ & $(0.0008)$ & $(0.0007)$ & $(0.0007)$ & $(0.0010)$ & $(0.0010)$ \\
\hline \multirow[t]{2}{*}{$T q_{i t}$} & -0.0009 & -0.0009 & 0.0001 & 0.0001 & $-0.0006^{*}$ & $-0.0006^{*}$ & 0.0002 & 0.0002 \\
\hline & (0.0005) & $(0.0005)$ & (0.0003) & (0.0003) & (0.0003) & $(0.0003)$ & $(0.0004)$ & $(0.0004)$ \\
\hline \multirow[t]{2}{*}{$C f o_{i t}$} & $0.1264^{* * *}$ & $0.1266^{* * *}$ & $0.0716^{* * *}$ & $0.0712^{* * *}$ & $0.1219^{* * *}$ & $0.1219^{* * *}$ & $0.0760^{* * *}$ & $0.0757^{* * *}$ \\
\hline & $(0.0085)$ & $(0.0085)$ & $(0.0069)$ & $(0.0069)$ & $(0.0076)$ & $(0.0076)$ & $(0.0084)$ & $(0.0084)$ \\
\hline Obs. & 12496 & 12496 & 15370 & 15370 & 15626 & 15626 & 12240 & 12240 \\
\hline $\mathrm{AR}(2)$ & 0.173 & 0.168 & 0.133 & 0.145 & 0.166 & 0.159 & 0.137 & 0.130 \\
\hline Hansen & 0.699 & 0.725 & 0.727 & 0.569 & 0.609 & 0.718 & 0.791 & 0.788 \\
\hline
\end{tabular}

Notes: Same as Table 1.

Finally, with the PIL framework, the instant and cumulative effects of financialization on real investment are plotted in Figure 2. In particular, the negative instant impact converges to zero at first 4.5 years and then reverts to be positive, while the cumulative effect manifests a "U-type" pattern. Specifically, the cumulative effect of financialization reaches the negative peak in year 4.5 and then shrinks, and eventually reverting to be negative after 11.5 years in full sample. Moreover, the subsample results of firms with large size and private ownership are similar. These results suggest that financialization could crowd out real investment in the short-term, but financialization supports real investment in the long-term. Our findings are consistent with the portfolio choice theory and the new Keynesian investment theory. 
(A) Full Sample

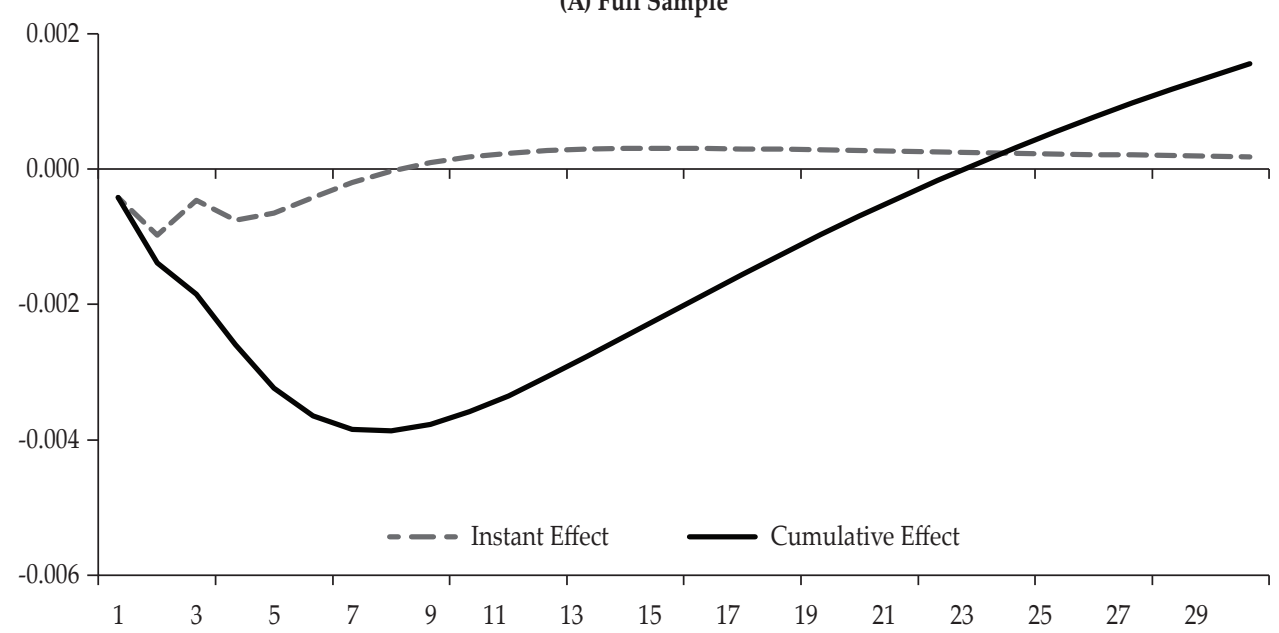

(b) Large Size Firms

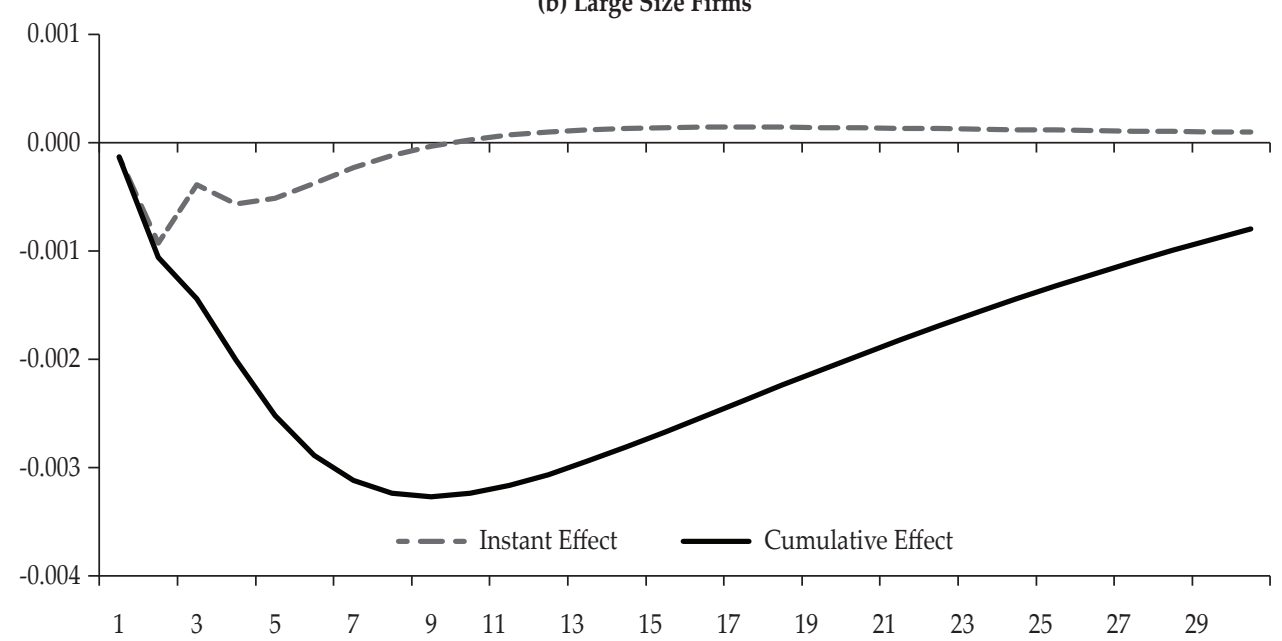

Figure 2. The Instant and Cumulative Effects of (Broad) Financialization on Real Investment 


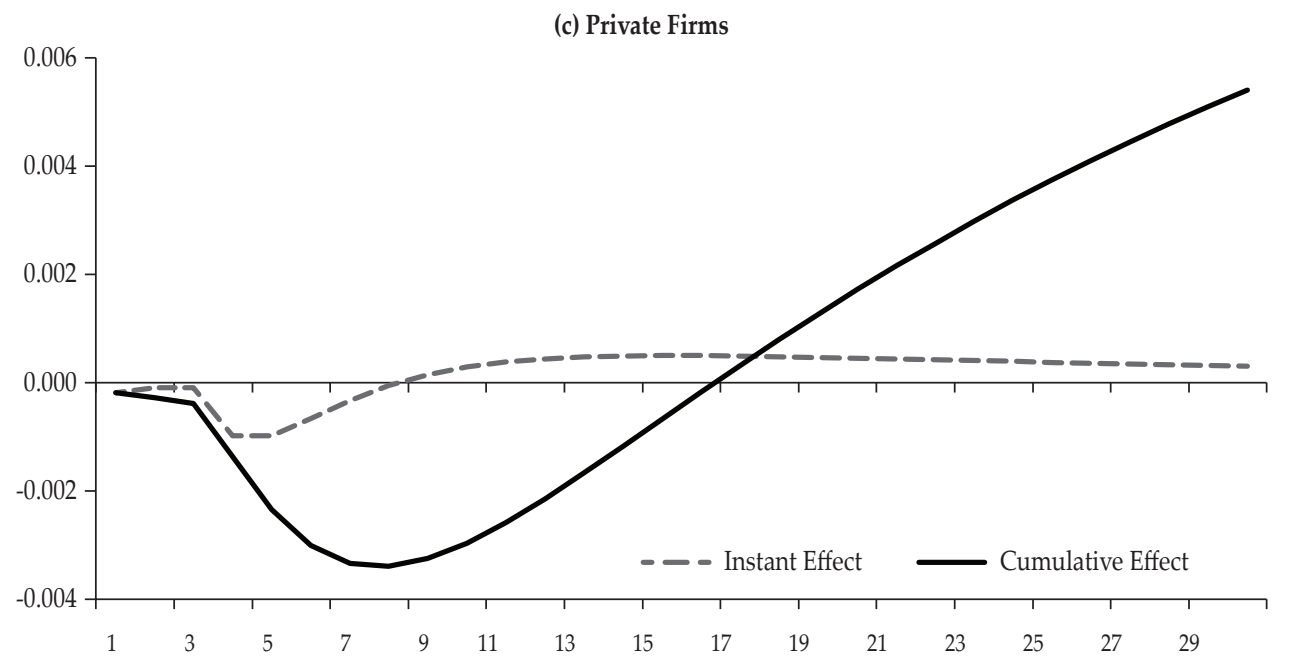

Figure 2. The Instant and Cumulative Effects of (Broad) Financialization on Real Investment (Continued)

In order to test for the robustness of previous conclusions, the following sensitivity tests are conducted: (i) re-estimating the regressions using those observations with residuals that do not exceed two standard deviations from zero; (ii) repeating the estimations using a balanced firm data; (iii) adding more micro and macro control variables; and (iv) dropping the data associated with negative financial profit from the sample. In all these cases, the robustness estimation results are not much dissimilar to those reported.

\section{CONCLUSIONS}

In this paper, we investigate the role of financialization in explaining China's stagnant capital accumulation. The results show that increased financial profit significantly reduces real investment, especially for small and private firms. Also, the effect of financialization on real investment is shown to be nonlinear, and manifests a "U-type" pattern across time horizons. Our findings provide some evidence that the relationship between financial and real investments can be substituted and complementary in the short and long-term. Thus, financialization may be the self-selection results of firm's portfolio choice under multiple investment options.

\section{REFERENCES}

Arellano, M., and Bover, O. (1995). Another look at the instrumental-variable estimation of error-components models. Journal of Econometrics, 68(1), 29-51.

Arrighi, G. (1994). The Long Twentieth Century: Money, Power, and the Origins of Our Times. London: Verso Press. 
Blundell, R., and Bond, S. (1998). Initial conditions and moment restrictions in dynamic panel data models. Journal of Econometrics, 87(1), 115-143.

Brown, J.R., and Petersen, B.C. (2011). Cash holding and R\&D smoothing. Journal of Corporate Finance, 17(4), 694-709.

Chaney, T., Sraer, D., and Thesmar, D. (2012). The collateral channel: How real estate shocks affect corporate investment. American Economic Review, 102(6), 2381-2409.

Demir, F. (2009). Financial liberalization, private investment and portfolio choice: Financialization of real sectors in emerging markets. Journal of Development Economics, 88(2), 314-324.

Kliman, A., and Williams, S. (2015). Why 'financialization' hasn't depressed U.S. productive investment? Cambridge Journal of Economics, 39(1), 67-92.

Lazonick, W., and O'Sullivan, M. (2000). Maximizing shareholder value: A new ideology for corporate governance. Economy and Society, 29(1), 13-35.

Mitchell, D.W., and Speaker, P.J. (1986). A simple, flexible distributed lag technique: The Polynomial inverse lag. Journal of Econometrics, 31(3), 329-340.

Orhangazi, Ö. (2008). Financialisation and capital accumulation in the nonfinancial corporate sector: A theoretical and empirical investigation on the US economy: 1973-2003. Cambridge Journal of Economics, 32(6), 863-886.

Smith, C.W., and Stulz, R.M. (1985). The determinants of firms' hedging policies. Journal of Financial and Quantitative Analysis, 20(4), 391-405.

Stockhammer, E. (2004). Financialization and the slowdown of accumulation. Cambridge Journal of Economics, 28(5), 719-741.

Tobin, J. (1965). Money and economic growth. Econometrica, 33(4), 671-684.

Tornell, A. (1990). Real vs. financial investment: Can Tobin taxes eliminate the irreversibility distortion? Journal of Development Economics, 32(2), 419-444. 
This page is intentionally left blank 